\title{
PENGARUH KONSENTRASI GARAM DAN LAMA WAKTU PERENDAMAN TERHADAP CITA RASA IKAN TERBANG (Hirundichthys oxycephalus) ASIN KERING
}

\author{
Nanda Usmany ${ }^{1}$, S. Liline ${ }^{2}$ \\ ${ }^{1}$ Alumni Program Studi Pendidikan Biologi \\ ${ }^{2}$ Program Studi Pendidikan Biologi \\ E-mail: sinline28@yahoo.com
}

\begin{abstract}
Background: Flying fish (Hirundichthys oxycephalus) is one type of fish that has a high economic value in Maluku waters. Flying fish (Hirundichthys oxycephalus) are usually consumed in the form of salted fish. However, not all salting techniques in salted fish produce good products and guaranteed quality. This study aims to determine the effect of salt concentration and immersion time on the taste of dried salted (Hirundichthys oxycephalus) flying fish.

Methods: This study was analyzed descriptively to assess organoleptics based on panelists using certain scores for the categories of appearance, aroma and taste. The research was conducted from September 5 to 192018.

Results: The study showed that the best products for processing dried salted fish were $40 \%$ salt concentration and 3-hour immersion time which obtained an organoleptic value of 5.91.

Conclusion: salt concentration and immersion time did not give a significant effect on the parameters of appearance, aroma, but affect the taste of dried salted flying fish.
\end{abstract}

Keywords: Salt concentration, immersion time, flying fish (Hirundichthys oxycephalus).

\begin{abstract}
Abstrak
Latar Belakang: Ikan terbang (Hirundichthys oxycephalus) merupakan salah satu jenis ikan yang memiliki nilai ekonomis cukup tinggi di perairan Maluku. Ikan terbang (Hirundichthys oxycephalus) biasa dikonsumsi dalam bentuk ikan asin. Akan tetapi tidak semua teknik penggaraman pada ikan asin tersebut menghasilkan produk yang bagus dan terjamin mutunya. Penelitian ini bertujuan untuk mengetahui pengaruh konsentrasi garam dan lama waktu perendaman terhadap cita rasa ikan terbang (Hirundichthys oxycephalus) asin kering.

Metode: Penelitian ini dianalisis secara deskriptif untuk menilai organoleptik berdasarkan panelis dengan menggunakan skor-skor tertentu untuk kategori kenampakan, aroma dan rasa. Penelitian dilaksanakan mulai dari tanggal 5 - 19 September 2018.

Hasil: Penelitian menunjukan bahwa produk terbaik untuk pengolahan ikan terbang asin kering yaitu perlakuan konsentrasi garam $40 \%$ dan lama perendaman 3 jam yang memperoleh nilai organoleptik 5.91 .

Kesimpulan: konsentrasi garam dan lama perendaman tidak memberi pengaruh yang nyata terhadap parameter kenampakan, aroma, tetapi berpengaruh terhadap rasa ikan terbang asin kering.
\end{abstract}

Kata Kunci :Konsentrasi garam, waktu perendaman, ikan terbang (Hirundichthys oxycephalus). 


\section{PENDAHULUAN}

Indonesia merupakan salah satu negara kepulauan, dimana hampir $70 \%$ luas negaranya adalah perairan dan $30 \%$ adalah daratan. Perairan Indonesia yang luas membuat Indonesia memiliki potensi perikanan yang cukup besar (Hartoyo, 2002). Sumber daya perikanan umum yang dapat dimanfaatkan untuk pengembangan budidaya perikanan meliputi: perairan tawar seperti sungai, waduk, saluran irigasi teknis, rawa dan danau; perairan payau seperti tambak, hutan bakau; dan perairan laut, sehingga banyak jenis (spesies) ikan yang hidup atau menghuni diperairan umum (Cahyono, 2001).

Ikan merupakan salah satu sumber protein yang sangat dibutuhkan manusia. Kandungan protein ikan sangat tinggi, kadar lemaknya lebih rendah jika dibandingkan dengan sumber protein hewani yang lain, dan harga ikan juga relatif lebih murah, sehingga ikan menjadi menu makanan yang sangat disukai oleh masyarakat pada umumnya. Ikan juga memiliki kekurangan yaitu lebih muda rusak dan memiliki daya tahan penyimpanan yang tidak lama pada suhu ruang. Sehingga diperlukan sebuah proses pengolahan lebih lanjut agar dapat memperpanjang daya simpannya (Nurjani, dkk, 2009).

Proses pembusukan ikan dapat disebabkan terutama oleh aktivitas enzim yang terdapat didalam tubuh ikan sendiri, aktivitas mikroorganisme, atau proses oksidasi pada lemak tubuh oleh oksigen dari udara. Kelemahan-kelemahan yang dimiliki oleh ikan telah dirasakan sangat menghambat usaha pemasaran hasil perikanan dan tidak jarang menimbulkan kerugian besar, terutama pada saat produksi ikan melimpah (Afrianto dan Liviawaty, 1989).

Proses pengolahan dan pengawetan ikan merupakan salah satu bagian penting dari mata rantai industri perikanan. Tanpa adanya kedua proses tersebut, peningkatan produksi ikan yang telah dicapai selama ini akan sia-sia, karena tidak semua produk perikanan dapat dimanfaatkan oleh konsumen dalam keadaan baik. Pengawetan ikan secara tradisional bertujuan untuk mengurangi kadar air dalam tubuh ikan, sehingga tidak memberikan kesempatan bagi bakteri untuk berkembang biak. Ada bermacam-macam pengawetan ikan, antara lain dengan cara : penggaraman, pengeringan, pemindangan, pengasapan, peragian, dan pendinginan ikan (Margono dkk, 2000).

Salah satu hasil olahan ikan yang dapat dikembangkan dan mempunyai prospek pemasaran yang cukup cerah dan sudah dikenal adalah ikan asin. Pengolahan ikan asin adalah cara pengawetan ikan yang sederhana dan hingga saat ini masih banyak dilakukan orang diberbagai negara. Pengawetan ikan dengan menggunakan proses penggaraman akan menghambat pertumbuhan bakteri pembusuk (Pseudomonas sp., Sarcina sp., Serratia sp, Achromobacter sp, Flavobacterium sp, Micrococcus sp, Vibro sp (Gozali, 2004). Penggunaan garam sebagai pengawet karena garam mempunyai kemampuan untuk menghambat pertumbuhan bakteri dan kegiatan enzim penyebab pembusukan yang terdapat didalam tubuh ikan. Cara

pengawetan ini merupakan cara yang paling mudah dari proses pengawetan ikan lainnya. Dasar inilah yang digunakan untuk mengawetkan ikan dengan garam (Gozali, 2004).

Ikan terbang (Hirundichthys oxycephalus) merupakan salah satu jenis ikan yang memiliki nilai ekonomis cukup tinggi tertangkap di perairan Maluku. Dari hasil tangkapan ikan terbang (Hirundichthys oxycephalus) lebih dari setengahnya dikonsumsi dalam bentuk segar dan setengahnya lagi dikonsumsi dalam bentuk ikan asin. Akan tetapi tidak semua teknik penggaraman pada ikan asin tersebut menghasilkan produk yang bagus dan terjamin mutunya. Hal itu karena tidak adanya takaran garam yang pasti untuk jumlah bahan yang digunakan. Penggunaan kosentrasi yang tepat dan pengolahan yang sempurna diharapkan dapat menghasilkan ikan asin yang baik mutunya.

\section{MATERI DAN METODE}

Jenis penelitian ini adalah penelitian eksperimen. Penelitian eksperimen digunakan untuk mengetahui pengaruh konsentrasi garam dan lama waktu perendaman terhadap cita rasa ikan terbang asin kering. Penelitian ini 
dilaksanakan di Laboratorium Biologi Dasar

Biologi FKIP Unpatti, dilaksanakan mulai dari tanggal 5 - 19 September 2018.

Objek dalam penelitian ini yaitu ikan terbang yang masih segar sebanyak 27 ekor, untuk 9 kali perlakuan dan $3 x$ ulangan, dengan menggunakan dua variabel yaitu variabel bebas dan terikat. Variabel bebas meliputi konsentrasi garam dapur 30\%, 40\% dan 50\%. Sedangkan variabel terikat dalam penelitian ini adalah cita rasa ikan terbang asin kering dengan indikator, kenampakan, aroma, rasa. tahap pembuatan ikan terbang asin kering kemudian dibagi menjadi 4 yaitu, menyiapkan daging ikan sesuai dengan konsentrasi $30 \%$, 40\% dan 50\%. Tahap selanjutnya yaitu perendaman didalam larutan garam selama 3 jam, 5 jam dan 7 jam, penirisan larutan garam dan pengeringan selam 2-3 hari dibawah sinar matahari. Dilakukan pengamatan kenampakan, aroma dan rasa dari ikan terbang asin kering. Data yang diperoleh
Pendidikan

seterusnya dianalisis secara statistik deskritif. Statistik deskriptif digunakan untuk menilai organoleptik berdasarkan panelis dengan menggunakan skor-skor tertentu untuk kategori kenampakan, aroma dan rasa.

\section{HASIL DAN PEMBAHASAN}

Produk ikan terbang asin dilakukan pengujian cita rasa dengan indikator berupa kenampakan, aroma dan rasa. Jumlah panelis yang terlibat dalam penilaian cita rasa ikan terbang asin adalah sebanyak 15 orang. Urut-urutan hasil uji cita rasa ikan terbang asin berdasarkan indikator yang tersaji sebagai berikut:

\section{Kenampakan}

Hasil pengamatan uji organoleptik kenampakan pada ikan terbang asin kering dapat dilihat hasil skor angka melalui tabel 1 berikut:

\section{Tabel 1. Hasil Penilaian Panelis Terhadap Kenampakan Ikan Terbang}

\begin{tabular}{ccccc}
\hline $\begin{array}{c}\text { Konsentrasi } \\
(\%)\end{array}$ & \multicolumn{3}{c}{$\begin{array}{c}\text { Lama Perendaman (Jam) } \\
\text { (B) }\end{array}$} & Rata-rata \\
\cline { 2 - 4 }$(\mathbf{A})$ & $\mathbf{3 ~ J a m}$ & $\mathbf{5 ~ J a m}$ & $\mathbf{7 ~ J a m}$ & \\
\hline $30 \%$ & 6 & 5.33 & 5 & 16.33 \\
$40 \%$ & 5.87 & 5.2 & 4.93 & 5.33 \\
$50 \%$ & 5.47 & 5.13 & 4.67 & 5.09 \\
\hline Rata-rata & $\mathbf{5 . 7 8}$ & $\mathbf{5 . 2 2}$ & $\mathbf{4 . 8 7}$ & \\
\hline
\end{tabular}

Rata-rata uji organoleptik kenampakan tertinggi diperoleh pada perlakuan $30 \%$ dengan lama perendaman 3 jam yaitu 6 sedangkan rata-rata terendah diperoleh pada perlakuan $50 \%$ dengan lama perendaman 7 jam yaitu 4,67. Hasil analisis menunjukan bahwa pemberian kadar garam memberikan pengaruh terhadap kenampakan ikan terbang asin kering. Kenampakan ikan terbang asin kering kurang lebih terlihat sama untuk semua perlakuan dan tidak terdapat kerusakan fisik serta tidak adanya perubahan warna yang berarti, selain itu kadar garam yang semakin tinggi, membuat penerimaan panelis cenderung semakin menurun. Ini dibuktikan dengan jumlah rata-rata kenampakan pada kadar garam 50\% dengan lama perendaman 7 jam berada pada angka terendah yaitu 4,67. Konsentrasi garam yang semakin tinggi diduga menyebabkan kenampakan ikan terbang asin kering terlihat lebih putih karena kristal garam yang terdapat pada permukaan tubuh ikan sehingga tingkat kesukaan panelis berkurang.

Menurut Rinto, dkk. (2009), menyatakan bahwa tingginya konsentrasi garam pada pengolahan ikan asin dan dilakukan penggaraman berulang akan menyebabkan ikan asin menjadi lebih putih karena adanya kristal garam. Ditambahkan juga oleh Rahmani, dkk.(2007) bahwa, semakin tinggi konsentrasi garam dan lama penggaraman akan menyebabkan semakin banyak butiran garam pada ikan asin. Dari hasil diatas menunjukan pada kadar garam $30 \%$ dengan lama perendaman 3 jam 
memiliki tingkat warna atau kenampakan yang disukai panelis dengan rata-rata tertinggi yaitu 6 . Sedangkan yang mendapatkan rata-rata warna/ kenampakan terendah berada pada kadar garam 50\% dengan lama perendaman 7 jam.

\section{Aroma}

Hasil pengamatan melalui uji organoleptik tingkat aroma pada ikan terbang asin kering dapat dilihat hasil skor angka melalui tabel 2 berikut :

\section{Tabel 2. Hasil Penilaian Panelis Terhadap Aroma Ikan Terbang Asin Kering}

\begin{tabular}{ccccc}
\hline $\begin{array}{c}\text { Konsentrasi } \\
\text { (\%) }\end{array}$ & \multicolumn{3}{c}{$\begin{array}{c}\text { Lama Perendaman (Jam) } \\
\text { (B) }\end{array}$} & Rata-rata \\
\cline { 2 - 4 } (A) & 3 Jam & 5 Jam & 7 Jam & \\
\hline $30 \%$ & 5.73 & 5.46 & 5.73 & 5.64 \\
$40 \%$ & 5.87 & 5.53 & 5.33 & 5.58 \\
$50 \%$ & 4.8 & 5.46 & 5.33 & 5.19 \\
\hline Rata-rata & 5.46 & 5.48 & \multicolumn{2}{c}{5.46} \\
\hline
\end{tabular}

Berdasarkan hasil uji tingkat aroma menunjukan bahwa dengan perlakuan berupa pemberian kadar garam berbeda memberikan pengaruh sangat nyata untuk mempertahankan kesegaran aroma pada ikan terbang asin kering. Rata-rata uji organoleptik tingkat aroma tertinggi diperoleh pada perlakuan $40 \%$ dengan lama perendaman 3 jam dengan nilai 5.87 sedangkan rata-rata terendah diperoleh pada perlakuan $50 \%$ dengan lama perendaman 3 jam dengan nilai 4.8. Hal ini dapat terjadi karena pemberian garam pada ikan berfungsi sebagai pengawet alami yang menghambat pertumbuhan mikroorganisme yang menyebabkan aroma busuk pada ikan.

Menurut Sani (2011) Pada umumnya aroma atau bau yang diterima oleh hidung dan otak lebih banyak merupakan campuran dari empat bau utama yaitu harum, tengik, asam dan hangus.

Kadar garam $40 \%$ selama 3 jam menunjukan hasil aroma terbaik pada ikan terbang asin kering. Pemberian garam mengakibatkan proses oksidasi menjadi terlambat sehingga ikan tidak memiliki aroma tengik. Ketika diberikan garam, maka akan terjadi proses osmosis yang akan menarik kadar air dari dalam ikan keluar, sehingga proses pembusukan tidak terjadi atau dihambat, dan ikan pun memiliki aroma yang khas serta disenangi oleh konsumen.

Rasa

Hasil pengamatan uji organoleptik tingkat rasa pada ikan terbang asin kering dapat dilihat hasil skor angka melalui tabel 3 berikut .

Tabel 3. Hasil Penilaian PanelisTerhadap Rasa Ikan Terbang Asin Kering

\begin{tabular}{ccccc}
\hline $\begin{array}{c}\text { Konsentrasi } \\
(\%)\end{array}$ & \multicolumn{3}{c}{$\begin{array}{c}\text { Lama Perendaman (Jam) } \\
\text { (B) }\end{array}$} & Rata-rata \\
\cline { 2 - 4 } (A) & 3 Jam & 5 Jam & 7 Jam & \\
\hline $30 \%$ & 5.87 & 5.87 & 5.13 & 5.62 \\
$40 \%$ & 6 & 5.67 & 4.33 & 5.33 \\
$50 \%$ & 5.26 & 4.6 & 3.4 & 4.42 \\
\hline Rata-rata & 5.71 & \multicolumn{3}{c}{5.38} \\
\hline
\end{tabular}

Pada Tabel 3 dari hasil uji cita rasa oleh panelis terhadap rasa ikan terbang asin menunjukan bahwa hasil penilaian panelis pada konsentrasi garam 30\% dan lama waktu perendaman 3 jam dan 5 jam memiliki nilai kesukaan tertinggi 5.87 dan kesukaan terendah pada perendaman 7 jam dengan nilai 5.13. Penilaian panelis pada konsentrasi $40 \%$ dan lama perendaman 3 jam memiliki nilai kesukaan 
tertinggi 6 dan terjadi penurunan pada lama perendaman 5 jam dengan nilai 5.67 sedangkan kesukaan terendah pada lama perendaman 7 jam dengan nilai 4.33. Penilaian panelis pada konsentrasi $50 \%$ dan lama perendaman 3 jam memiliki nilai kesukaan tertinggi 5.26 dan terjadi penurunan pada lama perendaman 5 jam dengan nilai 4.6 sedangkan kesukaan terendah pada perendaman 7 jam dengan nilai 3.4. Berdasarkan hasil uji organoleptik maka rasa yang disukai oleh panelis yaitu tidak asin dan tidak terlalu asin.

Berdasarkan nilai rata-rata pada uji hedonik, terlihat bahwa semakin tinggi konsentrasi garam dan lama penggaraman, semakin rendah pula nilai penerimaan panelis terhadap rasa ikan terbang asin kering. Konsentrasi garam yang tinggi dan penggaraman yang semakin lama diduga menyebabkan tingkat keasinan ikan terbang asin kering semakin tinggi. Selain itu, subyektifitas dari panelis mungkin berpengaruh terhadap penilaian rasa ikan terbang asin kering yaitu ada yang menyukai produk dengan konsentrasi garam yang tinggi dan ada juga yang tidak menyukai. Zeitsev, dkk.(1969) bahwa konsentrasi garam yang tinggi menyebabkan rasa dari produk menjadi asin sekali dan kadang tidak disukai konsumen.

\section{Karakteristik Mutu Produk Terpilih}

Penentuan produk terbaik dilihat berdasarkan total nilai tertinggi pada perlakuan yang diuji. Dari hasil pengujian di dapatkan produk terpilih yaitu perlakuan $40 \%$ dengan lama perendaman 3 jam.

Tabel 4. Penentuan Produk Terpilih

\begin{tabular}{lccccccccc}
\hline \multirow{2}{*}{ Penilaian } & \multicolumn{3}{c}{$\mathbf{3}$ Jam } & \multicolumn{3}{c}{$\mathbf{5}$ Jam } & \multicolumn{3}{c}{$\mathbf{7 ~ J a m}$} \\
\cline { 2 - 10 } & $\mathbf{3 0 \%}$ & $\mathbf{4 0 \%}$ & $\mathbf{5 0 \%}$ & $\mathbf{3 0 \%}$ & $\mathbf{4 0 \%}$ & $\mathbf{5 0 \%}$ & $\mathbf{3 0 \%}$ & $\mathbf{4 0 \%}$ & $\mathbf{5 0 \%}$ \\
\hline Kenampakan & 6 & 5.87 & 5.47 & 5.33 & 5.2 & 5.13 & 5 & 4.93 & 4.67 \\
Aroma & 5.73 & 5.87 & 4.8 & 5.46 & 5.53 & 5.46 & 5.73 & 5.33 & 5.33 \\
Rasa & 5.87 & 6 & 5.26 & 5.87 & 5.67 & 4.6 & 5.13 & 4.33 & 3.4 \\
\hline Jumlah & $\mathbf{1 7 . 6}$ & $\mathbf{1 7 . 7 4}$ & $\mathbf{1 5 . 5 3}$ & $\mathbf{1 6 . 6 7}$ & $\mathbf{1 6 . 4}$ & $\mathbf{1 5 . 1 9}$ & $\mathbf{1 5 . 8 7}$ & $\mathbf{1 4 . 5 9}$ & $\mathbf{1 3 . 4}$ \\
Rata-rata & $\mathbf{5 . 8 7}$ & $\mathbf{5 . 9 1}$ & $\mathbf{5 . 1 7}$ & $\mathbf{5 . 5 5}$ & $\mathbf{5 . 4 6}$ & $\mathbf{5 . 0 6}$ & $\mathbf{5 . 2 9}$ & $\mathbf{4 . 8 6}$ & $\mathbf{4 . 4 6}$ \\
Rangking & $\mathbf{2}$ & $\mathbf{1}$ & $\mathbf{6}$ & $\mathbf{3}$ & $\mathbf{4}$ & $\mathbf{7}$ & $\mathbf{5}$ & $\mathbf{8}$ & $\mathbf{9}$ \\
\hline
\end{tabular}

\section{KESIMPULAN}

Berdasarkan hasil penelitian maka didapatkan kesimpulan bahwa konsentrasi garam dan lama perendaman tidak memberi pengaruh yang nyata terhadap parameter kenampakan, aroma, tetapi berpengaruh nyata terhadap rasa ikan terbang asin kering. Konsentrasi garam $40 \%$ selama 3 jam penggaraman merupakan kombinasi yang tepat untuk mendapatkan ikan terbang asin kering.

\section{DAFTAR PUSTAKA}

Aprianto dan Liviawatty, 1989. Pengawetandan Pengolahan Ikan. Penerbit Kanisius: Yogyakarta.

Cahyono, B., 2001. Budidaya Ikan Di Perairan Umum. Yogyakarta, Kanisius

Gozali H. Thomas., Dedi Muchtadi., Yaroh., 2004. Peningkatan Daya Tahan
Simpan "Sate Bandeng"

(Chanoschanos) dengan Cara

Penyimpanan Dingin dan Pembekuan. Jurusan Teknologi Pangan Fakultas

Teknik-Unpas. Infomatek Volume 6 Nomor 1 Maret : 51-66.

Hartoyo , D., Herie, P., \& Ikhsan, B.W., 2002. Sebaran Densitas Ikan Pelagik di Selat Bali Pada Musim Timur September 1998. Unit Pelaksana Teknis Baruna Jaya. BPP Teknologi.

Margono, T, Suryati, D, Hartinah, S. 2000. Ikan Asin Cara Kombinasi Penggaraman Dan Peragian (Ikan Peda). www.warintek.ristek.go.id. Manado, 24 Oktober 2011.

Nurjani, A., A. R. Simanjuntak., A. Yakinuddin., H. W. Febrianingrum., Hermansyah., dan S. Mentari. 2009. Teknik Penggaraman Pindang Ikan Yang Baik Dan Benar. Teknik 
Penggaraman Ikan Yang Baik Dan Benar. Makalah. IPB, Bpgor.

Rahmani, Yuniata, Martati, E. 2007. Pengaruh Metode Penggaraman Basah Terhadap Karakteristik Ikan Asin Gabus (Ophiocephalus striatus).Jurnal Teknologi Pertanian. Volume 8 Nomor 3 (Desember 2007). Diaskes tanggal 17 Desember 2012

Rinto, Arafah, E., Utama, B. Susila. 2009. Kajian Keamanan Pangan (Formalin, Garam Dan Mikrobia) Pada Ikan Sepat Asin Produksi Indralaya. Juanal Pembangunan Manusia. Volume 8 Nomor 2 Tahun 2009. Diaskes dari http://balitbang.sumselprov.co.id.

Sani, M. 2011. Upaya Pengolahan Ikan Patin (Pangasius pangasius) sebagai bahan baku ikan asin jambal roti. Skripsi. Program Studi Teknologi Hasil Perikanan. Fakultas Perikanan dan IImu Kelautan. Institut Pertanian Bogor. Boogor.

Zaitzev, 1969. First Curring and Processing. MIR Publising. Moscon. 